\title{
Consumptive hypothyroidism in solitary cutaneous haemangioma
}

\author{
Partha Pratim Chakraborty, ${ }_{1}^{1}$ Mitali Bera, ${ }_{1}^{2}$ Shinjan Patra, ${ }^{1}$ Suman Roy ${ }^{2}$
}

'Medicine, Midnapore

Medical College and Hospital, Midnapore, West Bengal, India ${ }^{2}$ Paediatrics, Midnapore Medical College and Hospital, Midnapore, West Bengal, India

\section{Correspondence to} Dr Partha Pratim Chakraborty, docparthapc@yahoo.co.in

Accepted 30 June 2017

\section{(1) \\ CrossMark}

To cite: Chakraborty PP, Bera M, Patra S, et al. BMJ Case Rep Published Online First: [please include Day Month Year]. doi:10.1136/ bcr-2017-221366

\section{DESCRIPTION}

A $2 \frac{1}{2}$-year-old boy had been diagnosed with primary hypothyroidism and was referred for persistently elevated thyroid stimulating hormone (TSH) despite regular supervised administration of a high dose of L-thyroxine $(15 \mu \mathrm{g} / \mathrm{kg} / \mathrm{day})$ for preceding 3 months. His developmental milestones (sitting with support at 6 months of age) were normal initially. His parents then noticed progressive lethargy, sleepiness, poor feeding, constipation, hoarse cry and delayed milestones that prompted a medical consultation. Thyroid function tests done a week after his birth for unconjugated hyperbilirubinaemia were normal. When the test was repeated at about 1.5 years of age, TSH came out to be 76 $\mu \mathrm{IU} / \mathrm{mL}$.

Clinical examination revealed short stature, facial puffiness, macroglossia with dry and coarse skin and a small umbilical hernia (figure 1). Thyroid was palpable at eutopic location. A cutaneous haemangioma $(12 \mathrm{~cm} \times 10 \mathrm{~cm})$ was present over the left suprascapular area (figure 2). The parents stated that the lesion had been present since birth and progressively increasing from a size of a pinhead to its current form.

Relevant investigations revealed the following:

Free thyroxine (FT4): $0.4 \mathrm{ng} / \mathrm{dL}$; free triiodothyronine (FT3): $0.3 \mathrm{pg} / \mathrm{ml}$; TSH: $152 \mu \mathrm{IU} / \mathrm{mL}$.

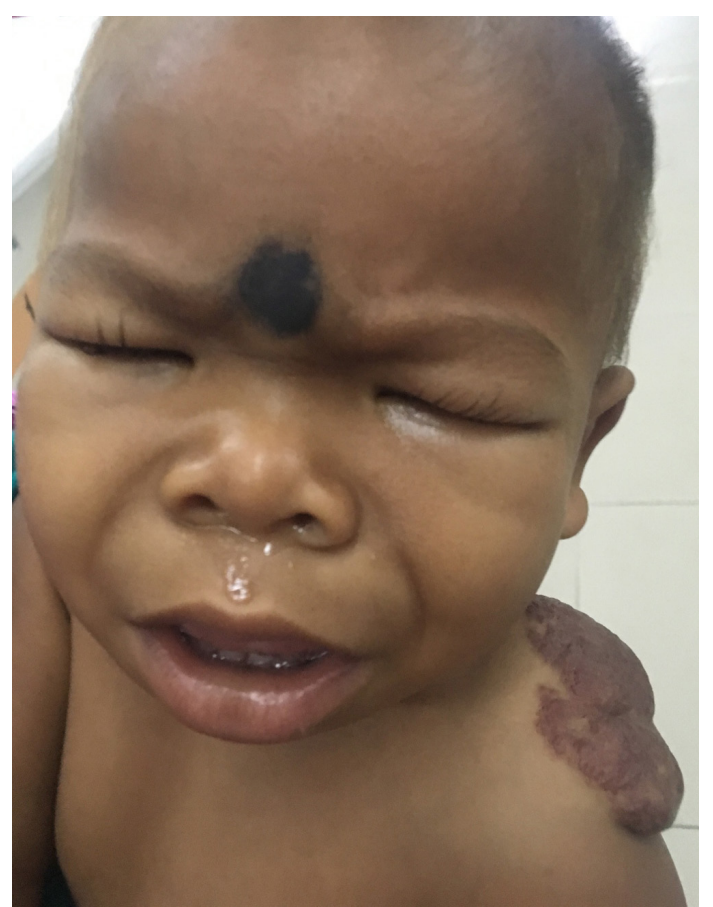

Figure 1 Facial puffiness suggestive of hypothyroidism.

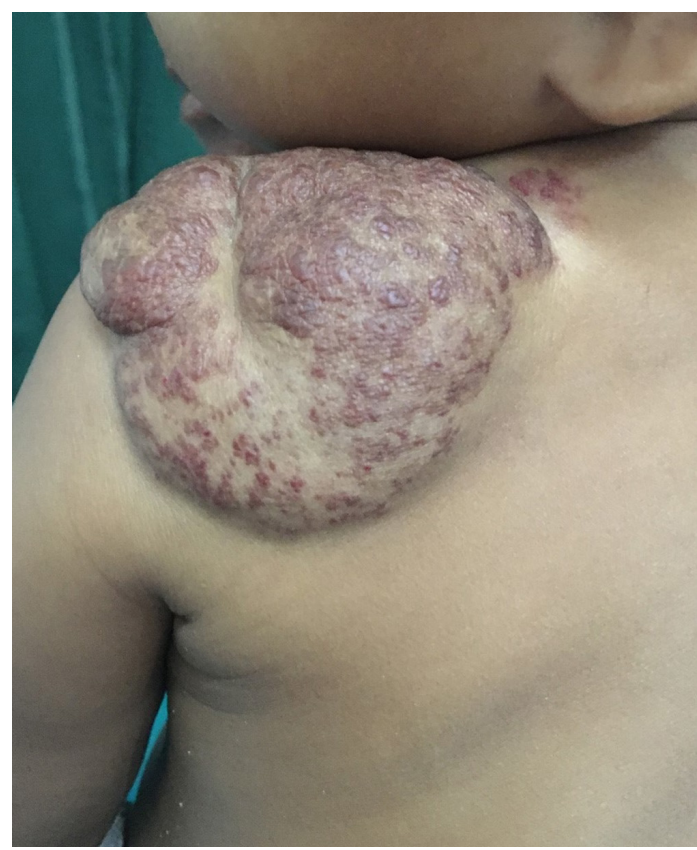

Figure 2 Solitary capillary haemangioma over left suprascapular area.

Thyroglobulin: $89 \mathrm{ng} / \mathrm{mL}$.

Neck ultrasonography, ${ }^{99 \mathrm{~m}}$ Tc-pertechnatate thyroid scan: normal-sized thyroid at eutopic location. Perchlorate discharge test: negative.

Ultrasonography and CT scan abdomen: normal.

We could not estimate circulatory reverse triiodothyronine ( $\mathrm{rT} 3$ ) concentration as none of the laboratories of our country perform this test. L-thyroxine was gradually increased to $40 \mu \mathrm{g} / \mathrm{kg} /$ day to achieve euthyroidism.

Hypothyroidism can be of three types: primary, secondary and peripheral. In peripheral hypothyroidism, also known as consumptive hypothyroidism, the hypothalamic-pituitary-thyroid axis is essentially normal both structurally and functionally; but there is excess degradation of active thyroid hormones $(\mathrm{TH})$ in the periphery. In healthy individuals, type 3 iodothyronine deiodinase (D3) enzyme breaks down T4 to rT3 and T3 to 3,3'-diiodothyronine (T2) both of which are biologically inactive. Vascular tumours like haemangioma at times express excessive amount of D3 and if the rate of inactivation surpasses the rate of the production of $\mathrm{TH}$, peripheral hypothyroidism develops.

Consumptive hypothyroidism is a rare variety of paraneoplastic syndrome first identified in newborns with infantile hepatic haemangiomatosis. ${ }^{1}$ It has been suggested that the development of hypothyroidism is strongly related to the amount 
and activity of the D3 enzyme, which is in turn directly proportional to the size of the tumour mass independent of its localisation. D3 activity is also known to increase rapidly during the proliferative phase of haemangioma.

Learning points

- Though consumptive hypothyroidism has been described mostly in association with hepatic haemangiomas and rarely in patients with multiple cutaneous haemangiomas, solitary cutaneous haemangioma can present with similar clinical manifestations.

- The clinical features and routine thyroid function of primary congenital hypothyroidism and consumptive hypothyroidism are identical. However, a negative neonatal thyroid screening test at birth, relatively late onset of symptoms, normal thyroid scintigraphy, elevated thyroglobulin and rT3 and a very high requirement of LT4 to achieve euthyroidism favours the diagnosis of consumptive hypothyroidism.

- Doctors, cutting across specialties and caregivers should be vigilant about hypothyroidism in all children with cutaneous haemangiomas, even if solitary as early detection and treatment of hypothyroidism is important to prevent growth retardation and intellectual impairment.
First reported in 2000, almost all the described cases of peripheral hypothyroidism are known to be associated with hepatic haemangioma, either solitary or multiple. Although this particular variety of hypothyroidism was initially described in infants, adult patients with consumptive hypothyroidism caused by D3-expressing gastrointestinal stromal tumour, vascular or fibroblastic tumours are increasingly being recognised. ${ }^{2}$

Peripheral hypothyroidism secondary to isolated cutaneous haemangioma without visceral involvement is rare and to the best of our knowledge only two such cases have been reported in children with multiple cutaneous capillary haemangiomas without a single case associated with such solitary cutaneous vascular malformation.

Contributors PPC was involved in diagnosis, patient management, literature search and writing the manuscript. MB, SP and SR were involved in patient evaluation and management.

Competing interests None declared.

Patient consent Obtained.

Provenance and peer review Not commissioned; externally peer reviewed.

(c) BMJ Publishing Group Ltd (unless otherwise stated in the text of the article) . All rights reserved. No commercial use is permitted unless otherwise expressly granted.

\section{REFERENCES}

1 Huang SA, Tu HM, Harney JW, et al. Severe hypothyroidism caused by type 3 iodothyronine deiodinase in infantile hemangiomas. N Engl J Med 2000;343:185-9.

2 Maynard MA, Marino-Enriquez A, Fletcher JA, et al. Thyroid hormone inactivation in gastrointestinal stromal tumors. N Engl J Med 2014;370:1327-34.

3 Luongo C, Trivisano L, Alfano F, et al. Type 3 deiodinase and consumptive hypothyroidism: a common mechanism for a rare disease. Front Endocrinol 2013;4:115.

Copyright 2017 BMJ Publishing Group. All rights reserved. For permission to reuse any of this content visit http://group.bmj.com/group/rights-licensing/permissions.

BMJ Case Report Fellows may re-use this article for personal use and teaching without any further permission.

Become a Fellow of BMJ Case Reports today and you can:

- Submit as many cases as you like

- Enjoy fast sympathetic peer review and rapid publication of accepted articles

- Access all the published articles

- Re-use any of the published material for personal use and teaching without further permission

For information on Institutional Fellowships contact consortiasales@bmjgroup.com

Visit casereports.bmj.com for more articles like this and to become a Fellow 